

MORE THAN MEDICINE 



\title{
MORE THAN MEDICINE
}

the broken promise of american health

\author{
Robert M. Kaplan
}

\author{
III \\ III \\ Harvard University Press \\ Cambridge, Massachusetts \\ London, England \\ 2019
}


Copyright (C) 2019 by the President and Fellows of Harvard College All rights reserved

Printed in the United States of America

First printing

9780674989184 (EPUB)

9780674989191 (MOBI)

9780674989207 (PDF)

The Library of Congress has cataloged the printed edition as follows:

Names: Kaplan, Robert M. (Robert Malcolm), 1947- author.

Title: More than medicine : the broken promise of American health /

Robert M. Kaplan.

Description: Cambridge, Massachusetts : Harvard University Press, 2019. I

Includes bibliographical references and index.

Identifiers: LCCN 2018024768 I ISBN 9780674975903 (hardcover : alk. paper)

Subjects: LCSH: Medical policy-United States. I Preventive health servicesUnited States. I Medicine, Preventive-United States. I Public healthUnited States.

Classification: LCC RA395.A3 K353 2019 | DDC 362.10973-dc23

LC record available at https://lccn.loc.gov/2018024768 
For the family that questions: Margaret, Cameron, Seth, Ashley, Oscar, and Rose 
